\title{
STRATEGI GURU PAI DALAM MENERAPKAN BUDAYA LITERASI UNTUK MENINGKATKAN MINAT BACA PESERTA DIDIK DI SMA NW SURALAGA
}

\author{
${ }^{1}$ M. Amin Rizki Suryadi, ${ }^{2}$ Muh Zulkifli, ${ }^{3}$ Komaruddin \\ ${ }^{123}$ Institut Agama Islam Hamzanwadi NW Lombok Timur \\ 1e-mail: rizkeysurya@gmail.com
}

\begin{abstract}
Abstrak: Siswa SMA NW Suralaga merupakan anak-anak yang masih perlu dibina dalam penerapan literasi baca, sebab belum memiliki kestabilan yang baik dalam penerapan literasi, dan dalam mengatur waktu sehari-hari. Guru PAI dan Guru staf yang lain mengetahui kekurangan dan kelebihan Strategi yang digunakan untuk menerapkan budaya Literasi kepada siswa dan siswi SMA NW Suralaga. Penelitian ini menggunakan pendekatan kualitatif yang menggunakan metode penelitian deskriftif dengan jenis penelitian lapangan (field research) yang berlokasi di SMA NW Suralaga. Data dalam penelitian ini dikumpulkan dengan menggunakan wawancara, observaasi, dan dokumentasi. Hasil penelitian ini adalah strategi guru PAI dalalm menerapkan budaya literasi untuk meningkatkan minat baca peserta didik SMA NW Suralaga yaitu, melalui bimbingan dan strategi, strategi pembiasaan, dan melalui event atau pertemuan medatangkan komuniytas-komunitas yang bergelut dibidang literasi, kunjungan ke Perpustakaan Daerah Lombok Timur untuk tour book satu kali dalam seminggu. kelebihan: meningkatkan minat baca siswa, meningkatkan pemahaman tentang literasi, meningkatkan kesadaran siswa dan menjadikan siswa terbiasa dalam menerapkan budaya literasi baca. Kekurangan: masih ada siswa yang lebih mementingkan hal-hal yang tidak bermanfaat kettika keluar main, seperti main game dan berolahraga ketika bukan jam olahraga, sehingga strategbi guru PAI untukn meningkatkan minat baca tidak terlaksanakan dengan maksimal untuk siswa dan siswi SMA NW Suralaga.
\end{abstract}

Kata Kunci: Strategi Guru PAI, Budaya Literasi, Meningkatkan Minat Baca

\begin{abstract}
SMA NW Suralaga students are children who still need to be nurtured in the application of reading literacy, because they do not yet have good stability in the application of literacy, and in managing daily time. PAI teachers and other staff teachers know the strengths and weaknesses of the strategies used to apply literacy culture to students at SMA NW Suralaga. This study uses a qualitative approach that uses a descriptive research method with the type of field study located at SMA NW Suralaga. Data in this study were collected using interviews, observations, and documentation. The result of this study is the strategy of PAl teachers in implementing literacy culture to increase reading interest of SMA NW Suralaga students through guidance and strategies, habituation strategies, and through events or meetings to bring in the community involved in literacy, visits to East Lombok Regional Library. to book a tour once a week. Strengths: increase students 'interest in reading, improve literacy comprehension, increase students' awareness and familiarize students with applying a culture of reading literacy. Disadvantages: there are still students who are more concerned with things that are not beneficial when going out to play such as playing games and exercising when not playing sports, so the strategy of PAl teachers to increase interest in reading is not implemented optimally to students at SMA NW Suralaga.
\end{abstract}

Keywords: PAI Teacher Strategies, Literacy Culture, Increase Interest in Reading 


\section{PENDAHULUAN}

Sejarah peradaban umat manusia menunjukkan bahwa bangsa yang maju tidak dibangun hanya dengan mengandalkan kekayaan alam yang melimpah dan jumlah penduduk yang banyak. Bangsa yang besar ditandai dengan masyarakatnya yang literat, yang memiliki peradaban tinggi, dan aktif memajukan masyarakat dunia. Keberliterasian dalam konteks ini bukan hanya masalah bagaimana suatu bangsa bebas dari buta aksara, melainkan juga yang lebih penting, bagaimana warga bangsa memiliki kecakapan hidup agar mampu bersaing dan bersanding dengan bangsa lain untuk menciptakan kesejahteraan dunia. Dengan kata lain, bangsa dengan budaya literasi tinggi menunjukkan kemampuan bangsa tersebut berkolaborasi, berpikir kritis, kreatif, komunikatif sehingga dapat memenangi persaingan global. Sebagai bangsa yang besar, Indonesia harus mampu mengembangkan budaya literasi sebagai prasyarat kecakapan hidup abad ke-21 melalui pendidikan yang terintegrasi, mulai dari keluarga, sekolah, sampai dengan masyarakat (Kemendikbud, 2017: 1).

Literasi bangsa adalah jalur penyediaan bahan bacaan dan pengembangan minat baca anak. Sebagai bagian penting dari peningkatan dan penumbuhan budi pekerti, karenanya perlu dipupuk dari dini utnk meningkatkan minat baca dan dari lingkungan keluarga juga enjadi hal yang paling terpenting dan utama. Minat baca yang tinggi, didukung dengan ketersediaan fasilitas-fasilitas buku baca yang bermutu dan terjangkau, hal ini akan mendorong pembiasaan membaca, baik di sekolah maupun di masyarakat. Dengan demikian kemampuan membaca akan tumbuh dan menjadi keterbiasaaan kepada anak atau peserta didik.

Dengan kemampuan membaca ini pula literasi dasar berikutnya (numerasi, sains, digital, finansial, serta budaya dan kewargaan) dapat ditumbuhkembangkan. vi Untuk membangun budaya literasi pada seluruh ranah pendidikan (keluarga, sekolah, dan masyarakat), sejak tahun 2016 Kementerian Pendidikan dan Kebudayaan menggiatkan Gerakan Literasi Nasional (GLN) sebagai bagian dari implementasi Peraturan Menteri Pendidikan dan Kebudayaan Nomor 23 Tahun 2015 tentang Penumbuhan Budi Pekerti. Layaknya suatu gerakan, pelaku GLN tidak didominasi oleh jajaran Kementerian Pendidikan dan Kebudayaan, tetapi digiatkan pula oleh para pemangku kepentingan, seperti pegiat literasi, akademisi, organisasi profesi, dunia usaha, dan kementerian/ lembaga lain. Pelibatan ekosistem pendidikan sejak penyusunan konsep, kebijakan, penyediaan materi pendukung, 
sampai pada kampanye literasi sangat penting agar kebijakan yang dilaksanakan sesuai dengan harapan dan kebutuhan masyarakat. GLN diharapkan menjadi pendukung keluarga, sekolah, dan masyarakat mulai dari perkotaan sampai ke wilayah terjauh untuk berperan aktif dalam menumbuhkan budaya literasi. Buku Peta Jalan, Panduan, Modul dan Pedoman Pelatihan Fasilitator, Pedoman Penilaian dan Evaluasi, dan Materi Pendukung Gerakan Literasi Nasional ini diterbitkan sebagai rujukan untuk mewujudkan ekosistem yang kaya literasi di seluruh wilayah Indonesia. Penghargaan yang tinggi saya sampaikan kepada tim GLN dan semua pihak yang terlibat dalam penyusunan buku ini. Semoga buku ini tidak hanya bermanfaat bagi Kementerian Pendidikan dan Kebudayaan selaku penggerak dan pelakunya, tetapi juga bagi masyarakat dan seluruh pemangku kepentingan dalam upaya membangun budaya literasi (Kemendikbud, 2017: 2). Berangkat dari permasalahan ini penulis menghususkan dalam skripsi ini untuk meneliti "Strategi Guru PAI dalam Menerapkan Budaya Lliterasi Untuk Meningkatkan Minat Baca Peserta Didik di SMA NW Suralaga" karena kegiatan Budaya Literasi Baca sangat berperan penting dalam meningkatkan pola piker dan kreatifitas siswa.

\section{METODELOGI PENELITIAN}

Penelitian ini menggunakan metode kualitatif dengan lingkungan alamiah sebagai sumber data. peristiwa-peristiwa yang terjadi dalam suatu situasi sosial merupakan kajian utama penelitian kualitatif. Peneliti pergi kelokasi tersebut, memahami dan mempelajari situasi. Studi dilakukan pada waktu interaksi berlangsung di tempat kejadian (Depdiknas, 2008: 22). Penelitian deskriftif adalah penelitian yang berusaha mendeskripsikan suatu gejala, peristiwa, kejadian yang terjadi saat sekarang. Penelitian deskriftif memusatkan perhatian pada masalahmasalah aktual sebagaimana adanya pada saat penelitian berlangsung (Depdiknas, 2008: 40). Selanjutnya Landasan teori yang dimanfaatkan sebagai pemandu agar focus penelitian sesuai dengan fakta dilapangan (Muh Zulkifli \& Rosli Hady, 2021: 47). 


\section{HASIL DAN PEMBAHASAN}

\section{Strategi Guru PAl dalam Menerapkan Budaya Literasi Untuk Mmeningkatkan Minat Baca Peserta Didik SMA NW Suralaga}

Strategi guru PAI merupakan suatu tindakan atau tugas seseorang gru dalam menggerakkan seluruh sumber daya atau siswa untuk memberikan secara instensif dalam memeberikan pembelajaran secara mandiri dan mengetahui dan menerapkan literasi khususnya menumbuhkan minat baca dengan strategi-strategi yang digunakan oleh sstiap guru secara umumnya. Dan strategi yang dilakukan adalah dengan meminta kesediaan guru dalam meningkatkan minat baca siswa. Selain itu beberapa strategi yang dilakukan oleh guru PAI dalam meningkatkan minat baca dengan memeberikan berbagai program yang menarik siswa untuk tetap ikut dalam menumbuhkan minat baca salah satunya adalah “Tour to Perpustakaan”. Program ini merupakan salah satu strategi yang dilakukan guru PAl untuk menumbuhkan minat baca siswa. Maka dari hal ini siswa mampu membiasakan siswa untuk pergi keperpustakaan untuk membaca buku.

Hal senada juga diungkapkan oleh Kepala SMA NW Suralaga:

"Selain memberikan mereka melaksanakan Tour Book ini mereka juga kami fasilitasi dengan buku-buku yang mereka minati, berkerja sama dengan komunitas-komunitas literasi, seperti Komunitas Literasi Madrasah dan TBM Khalifah Suralaga, maka itu yang meningkatkan minat sebagai daya tarik agar siswa tetap membiasakan diri untuk membaca" (Wawancara dengan Kepala SMA, 23/10/2021).

Proses pelaksanan program ini mempunyai hasil yang menjadikan siswa semakin membiasakan diri untuk selalu membaca, baik di sekolah maupun di rumah, siswa menjadi lebih baik dari yang sebelumnya, lebih berpikir dewasa dan memahami keadaan disekelilingnya. Berdasarkan pernyataan di atas, gru PAl selalu membiasakan untuk membimbing dan memotivasi siswa agar selalu membaca sehingga siswa terbiasa untuk melaksanakannya dilingkungan sekolah maupun di luar sekolah. 


\section{Kelebihan dan Kekurangan Strategi Guru PAl Dalam Menerapkan Budaya} Literasi Untuk Mmeningkatkan Minat Baca Peserta Didik SMA NW Suralaga

a. Kelebihan

Berdasarkan hasil penelitian bahwa kelebihan strategi dalam meningkatkan minat baca siswa SMA NW Suralaga yaitu:

1) Meningkatkan minat baca siswa dengan mudah

Strategi menumbuhkan minat baca pada siswa sangat memberikan kekuatan dan daya tarik untuk siswa tetap membiasakan diri untuk selalu membaca baik di sekolah ataupun luar sekolah.

Begitu juga ungkapan dari Guru PAI SMA NW Suralaga:

"Strategi ini sangat memberikan siswa agar tetap untuk membaca dan dapat mengkonsumsi bacaan-bacaan yang mereka baca setiap hari sehingga, siswa juga semakin memiliki pola pikir yang baik" (Wawancara dengan Guru PAI, 23/10/2021).

2) Menumbuhkan keterbiasaan membaca pada siswa

Beberapa strategi ampuh yang digunakan oleh guru PAI dalam menumbuhkan minat baca siswa, memiliki energy daya tarik yang kuat seingga siswa juga dapat memberikan edukasi terhadap teman sebayaknya untuk membiasakan diri untuk membaca menggunakan metode-metode yang digunakan oleh guru PAI tersebut.

b. Kekurangan

Berdasarkan hasil penelitian bahwa kekurangan Strategi dalam meningkatkan muinat baca siswa SMA NW Suralaga diantaranya:

1) Masih ada guru yang tidak memahami strategi

Berdasarkan hasil wawancara dengan Guru PAI SMA NW Suralaga:

"Kekurang dari strategi ini masih ada guru yang tidak sepaham dengan kita padahal kita sudah sosialisasikan terlebih dahulu, jadi ini yang membuat strategi terkadang tidak berjalan sesuai dengan apa yang diharapkan" (Wawancara dengan Guru PAI, 23/10/2021).

2) Masih ada siswa yang tidak mengikuti strategi

Siswa yang masih belum mendapatkan sentuhan dari guru-guru yang belum memahami strategi agar siswa dapat mengikutinya, dikarenakan juga kurangnya komunikasi antar siswa. 


\section{Faktor Pendukung dan Penghambat Strategi Guru PAl Dalam Menerapkan} Budaya Literasi Untuk Mmeningkatkan Minat Baca Peserta Didik SMA NW Suralaga

a. Faktor pendukung

Ada beberapa faktor yang menjadi pendukung upaya kepala madrasah dalam meningkatkan religiusitas siswa melalui Strategi yaitu:

1) Kepercayaan dan dukungan orang tua yang tinggi

Tingkat kepercayaan serta dukungan yang tinggi dari para orang tua siswa kepada lembaga SMA NW Suralaga ini terbilang tinggi, mereka para orang tua lebih open mind terhadap kebijakan-kebijakan yang dikeluarkan oleh pihak madrasah dan senantiasa memberikan dukungan. Seperti yang diungkapkan oleh bapak kepala madrasah SMA NW Suralaga

Berdasarkan pernyataan diatas dapat disimpulkan bahwa dukungan dari orang tua sangatlah penting dalam melaksanakan kegiatan sekolah, agar siswa-siswa nantinya menjadi pribadi yang lebih baik. Orang tua sudah tentu berharap agar anaknya menjadi pribadi yang lebih baik.

Orang tua juga terus mengawasi anak-anaknya ketika mereka sudah berada di rumah, karna kalau dirumah sudah menjadi tanggung jawab orang tua, dan apa yang siswa dapatkan di sekolah mereka akan mengamalkannya di rumah yaitu bagaimana mereka bersikap yang baik dan dapat menjadi educator literasi dirumahnya baik dengan keluarga dan teman sebayaknya.

2) Giatnya para guru dalam membimbing siswa

Giatnya para guru merupakan salah satu bentuk tanggunng jawab untuk memberikan edukasi literasi terkhusus untuk menumbuhkan minat baca kepada muridnya, dan juga bertanggung jawab membimbing siswa untuk memberikan motivasi agar siswa tetap atau istiqomah dalam membaca.

b. Faktor Penghambat

Adapun faktor penghambat upaya kepala madrasah dalam meningkatkan minat baca siswa di SMA NW Suralaga diantaranya: 
1) Faktor siswa sendiri

Salah satu faktor yang menghambat meningkatnya minat baca siswa yaitu dari diri mereka sendiri, mengingat tingkat penyerapan menangkap sebuah pelajaran siswa itu berbeda-beda terkadang ada yang lansung memahami dan juga lambat dalam memahami apa tujuan dari membiasakan diri untuk membaca. Berdasarkan pernyataan diatas bahwa faktor penghambat dalam strategi guru PAI dalam meningkatkan minat baca yaitu dari strategi yang tidak relevan atau yang tidakmenyesuaikan keadaan siswa dan siswi untuk membiasakan diri dalam membaca

2) Faktor lingkungan

Faktor lingkungan merupakan faktor yang paling dominan dalam menghambat meningkatnya minat baca siswa dimana tingkat pergaulan yang ada dimadrasah dengan lingkungan yang ada dirumah sangat berbeda, sehingga mereka berbaur dengan teman-teman mereka yang berbeda baik dari tingkah lakunya dan sikapnya. Seperti sekarang ini banyaknya siswa yang masih tidak perduli dengannya sendiri dan dikarenakan juga game online yang maraknya menjadi kegiatan atau aktivitas yang disukai. Berdasarkan pernyataan diatas faktor lingkungan merupakan salah satu penghambat meningkatnya minat baca siswa, mengingat siswa ketika mereka sudah pulang dari madrasah mereka sudah bebas atau lepas dari tanggung jawab guru-guru mereka.

\section{SIMPULAN}

Serangkaian pembahasan yang duraikan dalam naskah ini, maka dapat ditarik kesimpulan sebagai berikut:

1. Strategi guru PAI dalam meningkatkan minat baca siswa melalui kegiatan Book Tour dan mengadakan program membaca bersama di perpustakaan dengan bimbingan dari para guru-guru dan juga mendatangkan komunitas-komunitas yang bergelut dibidang literasi.

2. Kelebihan Strategi Guru PAI meningkatkan minat baca siswa di SMA NW Suralaga adalah Strategi ini bisa menarik siswa yang tidak pernah ingin membaca menjadi ingin untuk membaca dikarenakan daya tarik strategi dapat menumbuhkan minat baca siswa. 
3. Kekurangan Strategi Guru PAI meningkatkan minat baca siswa di SMA NW Suralaga adalah masih ada siswa yang belum tahu pentingnya membiasakan diri untuk membaca dan juga kekurangan guru edujator untuk menyampaikan atau mensosialisasikan tentang pentingnya membiasakan diri membaca dari dini.

\section{DAFTAR PUSTAKA}

Adiyanto, B. 2016. Strategi Guru Pendidikan Agama Islam (GPAI) Dalam Meningkatkan Religiusitas Siswa Muslim Di SMP Taman Harapan Malang. Skripsi UIN Maulana Malik Ibrahim malang.

Ainun, A. N., dkk. 2018. Mengenal Aqidah Dan Aqkhlak Islami, Lampung: Cv. Iqro.

Arif, R. N. P. 2019. Strategi Guru PAI Dalam Membentuk Karakter Religius Dan Mandiri Peserta Didik Melalui Kegiatan Ekstrakurikuler Keagamaan Di MAN 4 Madiun. Skripsi UIN Maulana Malik Ibrahim malang.

Arifin, Z. 2012. Pendidikan Multikultural Religius Untuk Mewujudkan Karakterpeserta Didik Yang Humanis Religius, Jurnal Pendidikan Agama Islam, 1(1):90-106.

Aslamiah, S. S. 2018. Upaya Guru PAI Dalam Meningkatkan Religiusitas Peserta Didik,Jurnal Akademika, 12(2):204-211.

Aviyah, E dan Farid, M. 2014. Religiusitas, Kontrol Diri Dan Kenakalan Remaja, Jurnal Psikologi Indonesia, 4(02):126-129.

Basri, H. 2009. Filsafat Pendidikan Islam, Bandung: Pustaka Setia.

Departemen pendidikan nasional, 2008. Pendekatan, Jenis, dan Metode Penelitian Pendidikan, Pdf.

Fitriani, I., dan Saumi A. 2018. Internalisasi Pendidikan Karakter Melalui Program Imtaq Dalam Membentuk Kepribadian Siswa, Jurnal Jurusan PGMI, 10(2): 7597.

Kholifah, S. 2011. Program Imtaq Dalam Membentuk Karakter Siswa Di SMAN 1 Plaret Bantul Yogyakarta, skripsi, UIN Sunan Kalijaga Yogyakarta.

Muchlinawarti. 2020. Pendidikan Karakter Berbasis Iman dan Taqwa Terhadap Peserta Didik, Jurnal Bidayah, 11(1): 1-14.

Reza, I. F. 2013.Hubungan Antara Religiusitas Dengan Moralitas Pada Remaja, Jurnal Studi Insana, 10(2):45-58.

Rifa'i, M. 2016. Implementasi Pembelajaran Integrated Antara Imtaq dan Imtek, Jurnal Pendidikan, 3(2): 36-45. 
Sahlan, A. 2017. Mewujudkan Budaya Religius Disekolah Upaya Mengembangkan PAI Dari Teori Ke Praktik, Malang: UIN-Maliki Press.

Sidik, U., dan Choiri, M. 2019. Metode Penelitian Kualitatif Di Bidang Pendidikan, Ponorogo: Cv. Nata Karya.

Sugiono. 2019. Metode Penelitian Kuantitatif, Kualitatif, Dan R\&D, Bandung: Alfabeta.

Suhur, S., 2018. Upaya Memebentuk Sikap Religiusitas Siswa Melalui Kegiatan Keagamaan Di Sekolah Dasar Islam Az-Zahrah Palembang.Skripsi UIN Raden Patah palembang.

Utama, I. K. A. B., dan Surya, I. K S. 2019. Pengaruh Religiusitas, Adversity Quotien dan Lingkungan Kerja Non Fisik Terhadap Stres Kerja,E-Jurnal Manajemen, 8(5): 3138-3165.

Walidin, W. S., dan Tabrani. 2015. Metodologi Penelitian Kualitatif Dan Grounded Theory, Aceh: FTK Ar-Raniry Aparess.

Wasil, B. 2017. Pengembangan Karakter Religius Siswa Melalui Kegiatan Imtaq Di SMPN 1 Jenangan Ponorogo. Skripsi institut agama islam negeri ponorogo.

Zulkifli, M., \& Hady, R. (2021). Penerapan Model Pembelajaran Langsung dalam Meningkatkan Prestasi Belajar Siswa Pada Mata Pelajaran Fiqih. An-Nahdlah: Jurnal Pendidikan Islam, 1(1), 44-56. 